\title{
Rola jednostek samorządu terytorialnego w zarządzaniu systemem opieki zdrowotnej w państwach członkowskich UE
}

\author{
The role of local and regional authorities in managing \\ the healthcare system in the EU Member States
}

\begin{abstract}
Streszczenie:
Opieka zdrowotna jest jednym z najważniejszych zadań publicznych współczesnego świata. Odpowiedzialność za funkcjonowanie systemu opieki zdrowotnej co do zasady spoczywa na władzy centralnej państwa. W Unii Europejskiej istnieją znaczne różnice pomiędzy organizacją systemów opieki zdrowotnej poszczególnych państw. Funkcjonują różne modele organizacyjne, odmienne są zasady finansowania oraz stopień decentralizacji. Artykuł przedstawia różne modele systemów ochrony zdrowia, koncentrując się głównie na roli władz lokalnych i regionalnych w systemach zarządzania zdrowiem. Rola ta jest analizowana pod względem stopnia samodzielności jednostek samorządu terytorialnego, zakresu ich kompetencji, zasad finansowania oraz odpowiedzialności i funkcji normatywnej. W artykule podjęto również próbę budowy modeli systemów opieki zdrowotnej w oparciu o rolę jednostek samorządu terytorialnego $\mathrm{w}$ ich zarządzaniu.
\end{abstract}

Słowa kluczowe: system opieki zdrowotnej, zdrowie publiczne, Unia Europejska, samorząd terytorialny

\footnotetext{
Abstract:

Healthcare is one of the most important public tasks in the modern world. Responsibility for the functioning of the health care system in principle rests with the central
} 
Robert Musiałkiewicz, Sylwia Sobczak - Rola jednostek samorządu...

state authorities. There are significant differences in the scope of its organization, funding principles and the degree of decentralization in the EU Member States. The article presents different models of health care systems, focusing mainly on the role of local and regional authorities in health management systems in EU Member States. This role is analyzed in terms of the degree of independence of local government units, the scope of their competences, funding rules, responsibilities and functions in relation to health protection legislation. The article also attempts to build models of health care systems based on the role of local and regional authorities in their management.

Keywords: health care system, public health, European Union, local self-government

\section{Wprowadzenie}

Problematyka funkcjonowania systemu opieki zdrowotnej jest przedmiotem permanentnej dyskusji akademickiej, sporów politycznych i konsultacji społecznych. Kształt systemu opieki zdrowotnej i jego praktyczna realizacja wzbudzają ogromne emocje na całym świecie. Podstawowym celem ochrony zdrowia jest zapewnienie mieszkańcom dostępu do świadczeń zdrowotnych na odpowiednim poziomie i w jak najszybszym terminie, niemniej realizacja tego celu przybiera różnorodne formy. Funkcjonujący obecnie w Unii Europejskiej (dalej: UE) model organizacji polityki zdrowotnej, w tym ochrony zdrowia, oparty jest na modelu państwowym, niezależnym od organów i instytucji UE. W poszczególnych państwach członkowskich Unii Europejskiej występują znaczne nierówności w sektorze zdrowia, zróżnicowana jest struktura demograficzna poszczególnych krajów oraz funkcjonują istotne dysproporcje w zakresie nakładów na system opieki zdrowotnej.

Samorząd terytorialny funkcjonuje we wszystkich państwach Unii Europejskiej¹. Jest wyrazem decentralizacji władzy publicznej. Jednak należy podkreślić, że jego struktury w poszczególnych państwach członkowskich są zorganizowane i działają na odmiennych zasadach.

\footnotetext{
${ }^{1}$ Zob. H. Izdebski, M. Kulesza, Administracja publiczna. Zagadnienia ogólne, Warszawa 2004, s. 205 i nast.
} 
W rozmaity sposób i używając różnych kryteriów, znawcy samorządu terytorialnego budują typologie opisujące to zróżnicowanie ${ }^{2}$. Jednym ze sposobów budowy modeli samorządów terytorialnych jest dzielenie ich ze względu na pochodzenie czy też genezę istniejących we współczesnych państwach ustrojów administracyjnych i politycznych. W ten sposób wyróżnia się samorządy terytorialne powstałe w wyniku działań decentralizacyjnych państw wcześniej scentralizowanych (zdecydowana większość państw europejskich) oraz samorządy terytorialne istniejące w wyniku „niecentralizacji” czyli istniejące tradycyjnie w krajach i państwach, w których władza nie została historycznie scentralizowana (Anglia, Szwecja) ${ }^{3}$. Innym sposobem podziału funkcjonujących w UE samorządów terytorialnych jest ich rozróżnienie ze względu na charakter i zakres decentralizacji władzy publicznej. Państwa członkowskie UE mają charakter unitarny, regionalny lub federalny. W państwach unitarnych decentralizacja realizowana jest przez przekazanie uprawnień administracyjnych głównie na poziom gminy i powiatu (departamentu), ale także regionu (województwa), przy zachowaniu unitarności i jednolitości ustrojowej. W państwach regionalnych decentralizacja jest szersza i obejmuje nie tylko delegowanie uprawnień ze szczebla centralnego na poziom samorządu, ale również zakłada podział władzy ustawodawczej między państwo a region autonomiczny. $\mathrm{W}$ państwach federalnych władza publiczna jest podzielona - część znajduje się przy państwie federalnym, a część przy kraju związkowym4 4 .

Celem niniejszych rozważań jest analiza roli i miejsca samorządów terytorialnych w krajowych systemach ochrony zdrowia krajów członkowskich UE. Przedmiotowe refleksje nie zawierają szczegółowego opisu zasad obowiązujących w poszczególnych krajach, koncentrują się, w oparciu o rolę samorządów terytorialnych w systemach ochro-

\footnotetext{
2 S. Faliński, Zróżnicowanie samorzq̨du terytorialnego w państwach Unii Europejskiej, „KNUV” 2014, nr 3, s. 73.

${ }^{3}$ H. Izdebski, Samorząd terytorialny. Podstawy ustroju i działalności, Warszawa 2011, s. 56.

${ }^{4}$ S. Faliński, Zróżnicowanie samorządu..., op. cit., s. 74.
} 
Robert Musiałkiewicz, Sylwia Sobczak - Rola jednostek samorzq̨du...

ny zdrowia, na wyodrębnieniu grup systemów/typów wykazujących podobieństwa według kryterium organizacyjnego i finansowego. Opracowanie zostało przygotowane przede wszystkim w oparciu o raport The management of health systems in the EU Member States. The role of local and regional authorities 5 przygotowany przez Rossellę Soldi oraz Cecilię Odone na zlecenie Komitetu Regionów EU.

\section{Rodzaje systemów opieki zdrowotnej}

Systemy opieki zdrowotnej mogą być klasyfikowane według różnych kryteriów ${ }^{6}$. W literaturze dominuje podział na cztery zasadnicze systemy: Bismarca, Siemaszki, Beverdige'a oraz rynkowy:

- system Bismarcka (społeczne ubezpieczenia zdrowotne) - według tego systemu pracownicy i pracodawcy płacą składki na społeczne ubezpieczenia zdrowotne do powołanych ustawowo instytucji ubezpieczeniowych - kas chorych, których zarządy niezależne od administracji państwowej zawierają kontrakty ze świadczeniobiorcami. Z kolei ubezpieczeni mają swobodny wybór kasy chorych7;

- system Siemaszki (system centralnie planowanej służby zdrowia) stworzył go pierwszy komisarz ludowy ds. zdrowia Nikołaj Aleksandrowicz Siemaszko. Zakłada on centralizację organizacji struktur i zasad finansowania. Zgodnie z tym modelem własnością państwa były wszystkie zakłady opieki zdrowotnej realizujące świadczenia medyczne, z kolei pracownicy byli traktowani jako urzędnicy państwowi8;

- system Beverdige'a (narodowy model służby zdrowia) - jego główną cechą jest wyraźne oddzielenie obszaru opieki zdrowotnej od całego sektora ochrony zdrowia, który jest finansowany z ogólnych

${ }^{5}$ R. Soldi, C. Odone, The management of health systems in the EU Member States The role of local and regional authorities; Committee of the Regions EU; ISBN: 978-92895-0943-5.

${ }^{6}$ E. Nojszewska, System ochrony zdrowia w Polsce, Warszawa 2011, s. 98.

7 J. Jończyk, Zasady i modele ochrony zdrowia, „Państwo i Prawo” 2010, nr 8, s. 9.

8 G. Jasiński, Wybrane aspekty organizacji i metod finansowania systemów ochrony zdrowia w państwach europejskich, „Biuletyn Kas Chorych” 2001, nr 3-4, s. 16-22. 
podatków nałożonych na obywateli. Środki finansowe pochodzące z podatków wchodzą w skład budżetu centralnego, gdzie są rozdzielane pomiędzy poszczególnymi sektorami lub bezpośrednio trafiają do budżetów lokalnych, które przeznaczają pewną ich część na ochronę zdrowia w danym regionie ${ }^{9}$;

- system rynkowy (rezydualny) - zakłada finansowanie ochrony zdrowia przez składki uiszczane $\mathrm{w}$ ramach prywatnego ubezpieczenia lub w ramach indywidualnej zapłaty za realizowaną usługę. Posiadanie ubezpieczenia jest obligatoryjne. Ze względu na powyższe w opisywanym modelu sektor ochrony zdrowia jest traktowany jako rynek zbytu, na którym dominującą rolę odgrywają popyt i podaż, a pacjent jest klientem ${ }^{10}$.

R. Soldi oraz C. Odone dodatkowo wskazują na podział systemów opieki zdrowotnej w oparciu o kryterium rodzaju płatników i dostawców świadczeń, wyróżniając trzy modele ${ }^{11}$ :

- model zintegrowany publicznie (the public integrated model) charakteryzuje się publicznymi płatnikami i publicznymi zakładami opieki zdrowotnej. W tym modelu pracownicy służby zdrowia są pracownikami sektora publicznego;

- model zamówień publicznych (the public contrach model) - w ramach tego modelu funkcjonują publiczni płatnicy oraz prywatni dostawcy usług opieki zdrowotnej;

- model prywatny (the private insurance/provider model) - zakłada funkcjonowanie prywatnych płatników oraz prywatnych dostawców usług opieki zdrowotnej.

${ }^{9}$ M. Kautsch, M. Whitfield, J. Klich (red.), Zarządzanie w opiece zdrowotnej, Kraków 2001, s. 32.; K. Wielicka, Zarys funkcjonowania systemów opieki zdrowotnej w wybranych krajach Unii Europejskiej, „Zeszyty Naukowe. Organizacja i Zarządzanie Politechnika Śląska" 2014, nr. 70, s. 494.

10 M. Rutkowska-Podołowska, Ł. Popławski, M. Zaleska-Tsitini, Health care policy in Poland and in selected European Union countries: Attempts at reducing fast increasing medical care costs, „The Małopolska School Of Economics in Tarnów, Papers Collection" 2011, nr 19, s. 132.

11 R. Soldi, C. Odone, The management of health..., op. cit., s. 8. 
Robert Musiałkiewicz, Sylwia Sobczak - Rola jednostek samorządu...

Europejska Federacja Szpitali HOPE (European Hospital and Healthcare Federation) oraz Dexia, dokonując klasyfikacji systemów opieki zdrowotnej w poszczególnych krajów członkowskich UE, oparły się na kryterium dominującego modelu zarządzania szpitalami, wyróżniając:

- model zdecentralizowany - zgodnie z tym modelem odpowiedzialność za zarządzanie szpitalami przeniesiono z państwa do władz regionalnych lub lokalnych;

- model zdekoncentrowany - zgodnie z tym modelem odpowiedzialność za zarządzanie szpitalami ponosi państwo (władza centralna), ale kompetencję do tego państwo przeniosło na samorząd terytorialny lub regionalne/lokalne oddziały administracji centralnej;

- model scentralizowany - za zarządzanie i funkcjonowanie systemu szpitalnego odpowiada wyłącznie władza centralna ${ }^{12}$.

Z kolei w analizach i badaniach OECD nad cechami instytucjonalnymi systemów opieki zdrowotnej państw członkowskich OECD I. Joumard, C. André i C. Nicq zaproponowali podział systemów opieki zdrowotnej państw członkowskich OECD według kryteriów funkcjonowania mechanizmu rynkowego regulujących popyt i podaż usług zdrowotnych, wyodrębniając:

- model dużego uzależnienia od mechanizmów rynkowych - wiodącą rolę sektora prywatnego w świadczeniu usług zdrowotnych oraz ochrony ubezpieczeniowej;

- model ograniczonego uzależnienia od prywatnej podaży, ale szeroki wybór dostawców usług medycznych;

- model dominującego systemu publicznego z ograniczonym wyborem dostawców ${ }^{13}$.

12 Hope \& Dexia, Hospitals in the 27 Member States of the European Union, Dexia Editions 2009; http://www.hope.be/wp-content/uploads/2015/11/79_2009_ OTHER_ Hospitals-in-27-Member-States-of-the-European-Union-eng.pdf; [dostęp: 2-01-2018].

13 I. Joumard, C. André, C. Nicq, Health Care Systems: Efficiency and Institutions, OECD Economics Department Working Papers, No. 769, OECD Publishing; http://www.oecd-ilibrary.org/economics/health-care-systems_5kmfp51f5f9t-en [dostęp: 2-02-2018]. 
W oparciu o kryterium uwzględnione w badaniach OECD oraz Europejskiej Federacji Szpitali HOPE można przyporządkować państwa członkowskie do określonych grup wskazanych w tabeli nr $1^{14}$.

Tabela 1. System ochrony zdrowia w państwach członkowskich UE

\begin{tabular}{|c|c|c|c|}
\hline \multirow{2}{*}{$\begin{array}{l}\text { Poziom } \\
\text { mechanizmów } \\
\text { rynkowych w } \\
\text { zakresie } \\
\text { świadczenia } \\
\text { usług } \\
\text { zdrowotnych }\end{array}$} & $\begin{array}{l}\text { Duże znaczenie } \\
\text { podmiotów } \\
\text { prywatnych }\end{array}$ & $\begin{array}{l}\text { Ograniczona } \\
\text { rola podmiotów } \\
\text { prywatnych, ale } \\
\text { szeroki wybór } \\
\text { dostawców }\end{array}$ & $\begin{array}{c}\text { Dominujący system } \\
\text { publiczny, } \\
\text { ograniczona rola } \\
\text { podmiotów } \\
\text { prywatnych }\end{array}$ \\
\hline & $\begin{array}{l}\text { Austria, Belgia, } \\
\text { Czechy, Francja, } \\
\text { Niemcy, Grecja, } \\
\text { Luksemburg, } \\
\text { Holandia, Słowacja }\end{array}$ & Szwecja & $\begin{array}{c}\text { Dania, Finlandia, } \\
\text { Węgry, Irlandia, } \\
\text { Włochy, Polska, } \\
\text { Portugalia, } \\
\text { Hiszpania, Wielka } \\
\text { Brytania }\end{array}$ \\
\hline \multirow[b]{2}{*}{$\begin{array}{c}\text { System } \\
\text { zarządzania } \\
\text { szpitalami }\end{array}$} & Zdecentralizowany & Scentralizowany & Zdekoncentrowany \\
\hline & $\begin{array}{c}\text { Austria, Belgia, } \\
\text { Czechy, Dania, } \\
\text { Finlandia, Niemcy, } \\
\text { Węgry, Włochy, } \\
\text { Łotwa, Litwa, Polska, } \\
\text { Słowacja, Hiszpania, } \\
\text { Szwecja, Wielka } \\
\text { Brytania }\end{array}$ & $\begin{array}{l}\text { Cypr, Estonia, } \\
\text { Irlandia, } \\
\text { Luksemburg, } \\
\text { Malta, Holandia } \\
\text { Rumunia, } \\
\text { Słowenia }\end{array}$ & $\begin{array}{l}\text { Bułgaria, Francja, } \\
\text { Grecja, Portugalia }\end{array}$ \\
\hline
\end{tabular}

Źródło: Opracowanie własne na podstawie R. Soldi, C. Odone; The management of health systems in the EU Member States The role of local and regional authoritie.

Powyższe zestawienie obrazuje różnorodność organizacyjną systemów ochrony zdrowia w poszczególnych państwach UE, ale też wskazuje na istnienie grup państw, gdzie funkcjonują zbliżone mechanizmy organizacyjne i finansowe.

\footnotetext{
14R. Soldi, C. Odone, The management of health..., op. cit., s. 9.
} 
Robert Musiałkiewicz, Sylwia Sobczak - Rola jednostek samorzq̨du...

\section{Rola jednostek samorządu terytorialnego w zarządzaniu systemem opieki zdrowotnej}

W celu dokonania oceny obecnej roli jednostek samorządu terytorialnego w zarządzaniu systemem opieki zdrowotnej analizie poddano przede wszystkim zasady finansowania opieki zdrowotnej oraz umocowanie kompetencyjne i odpowiedzialność samorządu terytorialnego za ochronę zdrowia, w tym zasady własności i zarządzania zakładami opieki zdrowotnej.

\section{1. Źródła finansowania opieki zdrowotnej}

Źródła finansowania opieki zdrowotnej są w poszczególnych krajach różne, a ich charakter zależy od wyboru politycznego dokonanego przez przedstawicieli społeczeństw ${ }^{15}$. W większości krajów podstawowa część nakładów na ochronę zdrowia pochodzi ze źródeł publicznych, niemniej ważną rolę pełnią środki prywatne pochodzące najczęściej z opłat bezpośrednich od pacjentów lub składek na dobrowolne ubezpieczenia zdrowotne.

Najwyższe całkowite wydatki w 2015 r. na opiekę zdrowotną w stosunku do PKB wśród państw członkowskich UE poniosły Szwecja, Francja, Niemcy i Holandia. Poziom wydatków na opiekę zdrowotną w Niemczech wyniósł 321 mld EUR, co stanowi najwyższą wartość wśród państw członkowskich UE16. Francja odnotowała drugi najwyższy poziom (237 mld EUR), a następnie Zjednoczone Królestwo (223 mld EUR). Wydatki na opiekę zdrowotną w przeliczeniu na jednego mieszkańca w 2014 r. były najwyższe w Szwecji (5,0 tys. EUR na mieszkańca) i Luksemburgu (5,6 tys. EUR na mieszkańca).

Do źródeł publicznych finansowania systemu ochrony zdrowia należy zaliczyć przede wszystkim środki budżetu państwa, jednostek

\footnotetext{
15 J. Suchecka (red.), Finansowanie ochrony zdrowia: Wybrane zagadnienia, Warszawa 2001, s. 92 i nast.

${ }^{16}$ Szerzej na temat systemu w Niemczech: M. Kluczyńska, J. Grzywacz; System finansowania publicznej opieki zdrowotnej $w$ Polsce w świetle doświadczeń niemieckich; „Zeszyty Naukowe PWSZ w Płocku Nauki Ekonomiczne” 2015, t. XXII.
} 
samorządu terytorialnego oraz środki funduszy celowych. Wszystkie powyższe pochodzą przede wszystkim z należności podatkowych o charakterze obligatoryjnym.

Zaangażowanie samorządu terytorialnego poszczególnych krajów członkowskich UE w finansowanie opieki zdrowotnej jest mocno zróżnicowane. Dane Eurostatu (tabela nr 2) pokazują, że finansowanie przez władze lokalne i regionalne występuje w 23 państwach członkowskich, nie ma go na Cyprze, w Grecji, Irlandii, Luksemburgu i na Malcie. Z kolei w Danii, Włoszech, Hiszpanii, Finlandii i Szwecji samorząd terytorialny finansuje większość całkowitych wydatków na służbę zdrowia. W Belgii, Niemczech, Francji, Holandii, Portugalii, Słowacji, Wielkiej Brytanii i na Węgrzech jego zaangażowanie finansowe nie przekracza $5 \%$.

Tabela 2. Zaangażowanie samorządu terytorialnego w finansowanie opieki zdrowotnej

\begin{tabular}{|c|c|c|c|}
\hline Kraj & $\begin{array}{c}\text { Całkowite wydatki } \\
\text { na służbę zdrowia } \\
\text { do PKB }\end{array}$ & $\begin{array}{c}\text { Wydatki } \\
\text { samorządu } \\
\text { terytorialnego na } \\
\text { służbę zdrowia do } \\
\text { PKB }\end{array}$ & $\begin{array}{c}\text { Udział procentowy } \\
\text { samorządu } \\
\text { terytorialnego } \\
\text { w całkowitych } \\
\text { wydatkach na } \\
\text { służbę zdrowie }\end{array}$ \\
\hline Belgia & 10,4 & 0,1 & 1,0 \\
\hline Bułgaria & 8,5 & 1,1 & 12,9 \\
\hline Czechy & 7,6 & 1,5 & 19,7 \\
\hline Dania & 10,4 & 8,4 & 80,8 \\
\hline Niemcy & 11 & 0,5 & 4,5 \\
\hline Estonia & 6,1 & 1,5 & 24,6 \\
\hline Irlandia & 9,9 & 0,0 & 0,0 \\
\hline Grecja & 8,3 & 0,0 & 63,7 \\
\hline Hiszpania & 9,1 & 5,8 & 0,9 \\
\hline Francja & 11,1 & 0,1 & 38,8 \\
\hline Chorwacja & 6,7 & 2,6 & \\
\hline
\end{tabular}




\begin{tabular}{|c|c|c|c|}
\hline \multicolumn{4}{|c|}{ Robert Musiałkiewicz, Sylwia Sobczak - Rola jednostek samorzq̨du... } \\
\hline Włochy & 9 & 7,0 & 77,8 \\
\hline Cypr & 6,8 & 0,0 & 0,0 \\
\hline Łotwa & 5,5 & 0,9 & 16,4 \\
\hline Litwa & 6,2 & 1,5 & 24,2 \\
\hline Luksemburg & 6,3 & 0,0 & 0,0 \\
\hline Węgry & 7,2 & 0,3 & 4,2 \\
\hline Malta & - & - & - \\
\hline Holandia & 10,9 & 0,5 & 4,6 \\
\hline Austria & 10,3 & 4,6 & 44,7 \\
\hline Polska & 6,3 & 2,0 & 31,7 \\
\hline Portugalia & 9 & 0,4 & 4,4 \\
\hline Rumunia & 5,1 & 1,3 & 25,5 \\
\hline Słowenia & 8,5 & 1,0 & 11,8 \\
\hline Słowacja & 7 & 0,2 & 2,9 \\
\hline Finlandia & 9,5 & 5,8 & 61,1 \\
\hline Szwecja & 11,1 & 6,7 & 60,4 \\
\hline Wielka Brytania & 9,9 & 0,2 & 2,0 \\
\hline
\end{tabular}

Źródło: Opracowanie własne na podstawie danych Eurostat: http://ec.europa.eu/ eurostat/statistics-explained/index.php/Healthcare_expenditure_statistics\# Healthcare_expenditure oraz http://ec.europa.eu/eurostat/data/database? node_code=hlth_sha11_hchf

\subsection{Zakres kompetencyjny samorządu terytorialnego}

Podstawową funkcją samorządu terytorialnego jest decentralizacja władzy, przesunięcie jej bliżej obywateli. Stanowi on istotny element konstrukcji władzy publicznej i jest wynikiem realizacji zasady pomocniczości ${ }^{17}$. Jego struktura, ustrój i organizacja są mocno zróżnico-

17 Zob. H. Izdebski, Polski samorzad terytorialny $w$ Europie. Aktualne problemy i wyzwania, [w:] K. Czarnecki, A. Lutrzykowski i R. Musiałkiewicz (red.), Samorzq̨d terytorialny w Polsce i Europie. Aktualne problemy $i$ wyzwania, Włocławek 2017, s. 16 i nast. 
wane w poszczególnych krajach członkowskich UE, różny jest jego zakres kompetencyjny, umocowanie do określonych działań. Owo zróżnicowanie dotyka również problematyki polityki zdrowotnej, w tym planowania, finansowania i świadczenia usług zdrowotnych.

R. Soldi oraz C. Odone, analizując zakres kompetencyjny samorządu terytorialnego w przedmiocie opieki zdrowotnej w poszczególnych krajach członkowskich UE, wskazały, że tylko w pięciu państwach władze lokalne i regionalne posiadają samodzielne kompetencje do stanowienia przepisów dotyczących polityki zdrowotnej. W sześciu państwach władze lokalne i regionalne są odpowiedzialne za politykę zdrowotną, w 15 państwach władze lokalne i regionalne mają obowiązek działań planistycznych w obszarze zdrowia, zaś w 23 państwach członkowskich władze lokalne i regionalne są odpowiedzialne za organizację lub świadczenie opieki zdrowotnej. Ponadto samorząd terytorialny jest właścicielem obiektów opieki zdrowotnej w 20 państwach członkowskich, ponosząc za te obiekty odpowiedzialność prawną i finansową, jest zobowiązany do zarządzania nimi, finansowania inwestycji oraz ponoszenia kosztów stałych i operacyjnych ${ }^{18}$.

\section{Rodzaje organizacji systemów zarządzania ochroną zdrowia}

Przedstawione w punkcie 2 rodzaje klasyfikacji mają charakter ogólny, obrazowy, nie wskazują na poziom decentralizacji ani nie opisują instytucjonalnych uwarunkowań poszczególnych systemów zarządzania zdrowiem. W rzeczywistości mechanizmy finansowania systemów opieki zdrowotnej oparte na opodatkowaniu publicznym mogą być zdecentralizowane (np. Dania) lub scentralizowane (np. Cypr), publiczni płatnicy/dostawcy mogą funkcjonować w ramach modelu scentralizowanego (np. Malta) lub modelu zdecentralizowanego (np. Włochy), z kolei dominujący publiczny system opieki zdrowotnej nie musi oznaczać scentralizowanego systemu zarządzania

18 R. Soldi, C. Odone, The management of health..., op. cit., s. 10. 
Robert Musiałkiewicz, Sylwia Sobczak - Rola jednostek samorzq̨du...

szpitalami. System ten może się opierać również na zasadzie decentralizacji (np. Polska, Hiszpania) lub dekoncentracji (np. Portugalia). Wobec powyższego R. Soldi oraz C. Odone zaproponowały następujący podział modeli systemów zarządzania zdrowiem:

- model zdecentralizowany,

- model częściowo zdecentralizowany,

- model operatywnie zdecentralizowany,

- model w większości scentralizowany,

- model scentralizowany.

\subsection{System zdecentralizowany}

System zdecentralizowany obejmuje pięć krajów: Austrię, Hiszpanię, Niemcy, Wielką Brytanię i Włochy. W tych krajach władze regionalne posiadają kompetencję ustawodawczą w zakresie ochrony zdrowia lub niektórych jej segmentów - przykładowo takich, jak opieka stacjonarna (Austria). Organy samorządowe (w tym regionalne) kompleksowo odpowiadają za zarządzanie systemem opieki zdrowotnej, w tym za jej planowanie, organizowanie i funkcjonowanie. Z wyjątkiem Wielkiej Brytanii finansowanie z budżetów lokalnych (jako \% PKB) znacznie przewyższa udział krajowy. Ponadto władze regionalne (a często również władze lokalne) posiadają kompetencje do ustalania i pobierania danin publicznych finansujących system opieki zdrowotnej. We wszystkich powyższych państwach władze regionalne są również odpowiedzialne prawnie za system opieki zdrowotnej, którego wdrażanie jest często przekazywane władzom lokalnym (np. w Niemczech). W systemie zdecentralizowanym można wskazać dwie tendencje. Pierwsza z nich to wzmocnienie mechanizmów współpracy i koordynacji między różnymi podmiotami systemu ochrony zdrowia. Tak jest w przypadku Włoch i Konferencji Państw-Regionów, a także Austrii, gdzie powołano nowe komitety organizacyjne i zarządzające w celu prowadzenia wspólnego zarządzania. Drugą tendencją jest wzmocnienie konkurencji w systemie opieki zdrowotnej poprzez prywatyzację usług zdrowotnych. Tak jest $\mathrm{w}$ przypadku Niemiec 
i Wielkiej Brytanii. W systemie ochrony zdrowia opartym na decentralizacji mogą pojawiać się istotne różnice $\mathrm{w}$ zasadach określających świadczenia opieki zdrowotnej $\mathrm{w}$ poszczególnych regionach. Taka sytuacja ma miejsce w Hiszpanii i we Włoszech, gdzie w poszczególnych regionach istnieje zróżnicowanie poziomu obowiązków oraz funkcji władz lokalnych i regionalnych. Problemem systemu zdecentralizowanego jest również brak adekwatności pomiędzy autonomią finansową a powierzonymi zadaniami publicznymi. W Austrii autonomia budżetowa władz regionalnych w zakresie kształtowania przychodów jest ograniczona, co utrudnia samodzielną realizację polityki ochrony zdrowia. Z kolei w Hiszpanii autonomia finansowa regionów przyczyniła się do ich znacznego zadłużenia, co z uwagi na zasadę stabilności budżetowej implikuje ograniczenie zdolności i możliwości rządu centralnego w zakresie polityki rozwoju ${ }^{19}$.

Tabela 3. Modele systemów zarządzania zdrowiem

\begin{tabular}{|c|c|c|c|c|c|}
\hline \multirow{2}{*}{$\begin{array}{c}\text { Kompetencje } \\
\text { JST }\end{array}$} & \multicolumn{5}{|c|}{ System } \\
\cline { 2 - 6 } & $\begin{array}{c}\text { zdecentra- } \\
\text { lizowany }\end{array}$ & $\begin{array}{c}\text { częściowo } \\
\text { zdecentra- } \\
\text { lizowany }\end{array}$ & $\begin{array}{c}\text { zdecentra- } \\
\text { lizowany } \\
\text { operatyw- } \\
\text { nie }\end{array}$ & $\begin{array}{c}\text { w większości } \\
\text { scentralizo- } \\
\text { wany }\end{array}$ & $\begin{array}{c}\text { scentra- } \\
\text { lizowany }\end{array}$ \\
\hline $\begin{array}{c}\text { Zdolność do } \\
\text { kształtowania } \\
\text { przychodów }\end{array}$ & Tak & Tak & Tak & Tak & Nie \\
\hline finansowania & $\begin{array}{c}\text { Powyżej } \\
\text { poziomu } \\
\text { centralnego } \\
\text { (wyjątek: } \\
\text { Wielka } \\
\text { Brytania) }\end{array}$ & $\begin{array}{c}\text { Powyżej } \\
\text { poziomu } \\
\text { centralnego }\end{array}$ & $\begin{array}{c}\text { Poniżej } \\
\text { poziomu } \\
\text { centralnego }\end{array}$ & $\begin{array}{c}\text { Poniżej } \\
\text { poziomu } \\
\text { centralnego }\end{array}$ & Brak \\
\hline
\end{tabular}

${ }^{19}$ Szerzej o konflikcie finansowym w Hiszpanii pomiędzy władzą centralną a samorządową: K. Piotrowska, J. Marczak, J. Marczak, T. Uryszek, Obszary konfliktów w systemie finansowym, „Dny práva - 2009 - Days of Law: the Conference Proceedings, 1. Editio", Masaryk University 2009, s. 8 i nast. 
Robert Musiałkiewicz, Sylwia Sobczak - Rola jednostek samorzqdu...

\begin{tabular}{|c|c|c|c|c|c|}
\hline $\begin{array}{l}\text { Kompetencje } \\
\text { ustawodawcze }\end{array}$ & Tak & Nie & Nie & Nie & $\mathrm{Nie}$ \\
\hline $\begin{array}{c}\text { Odpowiedzial- } \\
\text { ność za } \\
\text { planowanie }\end{array}$ & Tak & Tak & $\begin{array}{c}\text { Nie (wyjątki } \\
\text { Litwa, } \\
\text { Czechy) }\end{array}$ & $\begin{array}{c}\text { Tak, } \\
\text { w przypadku } \\
\text { określonych } \\
\text { segmentów }\end{array}$ & Nie \\
\hline $\begin{array}{l}\text { Odpowiedzial- } \\
\text { ność za } \\
\text { organizację } \\
\text { systemu }\end{array}$ & Tak & Tak & Tak & $\begin{array}{c}\text { Tak, } \\
\text { w przypadku } \\
\text { określonych } \\
\text { segmentów }\end{array}$ & Nie \\
\hline $\begin{array}{c}\text { Własność } \\
\text { i zarządzanie } \\
\text { obiektami }\end{array}$ & Tak & Tak & Tak & Nie & Nie \\
\hline Kraje & $\begin{array}{l}\text { Włochy, } \\
\text { Hiszpania, } \\
\text { Austria, } \\
\text { Niemcy, } \\
\text { Wielka } \\
\text { Brytania }\end{array}$ & $\begin{array}{l}\text { Szwecja, } \\
\text { Finlandia, } \\
\text { Dania, } \\
\text { Chorwacja } \\
\text { Polska, } \\
\text { Belgia }\end{array}$ & $\begin{array}{c}\text { Litwa, } \\
\text { Słowenia, } \\
\text { Łotwa, } \\
\text { Czechy, } \\
\text { Węgry, } \\
\text { Estonia, } \\
\text { Bułgaria, } \\
\text { Rumunia, } \\
\text { Słowacja }\end{array}$ & $\begin{array}{l}\text { Holandia, } \\
\text { Francja, } \\
\text { Portugalia }\end{array}$ & $\begin{array}{c}\text { Cypr, } \\
\text { Grecja, } \\
\text { Irlandia, } \\
\text { Luksembu } \\
\text { rg, Malta }\end{array}$ \\
\hline
\end{tabular}

Źródło: Opracowanie własne na podstawie R. Soldi, C. Odone; The management of health systems in the EU Member States The role of local and regional authorities.

\subsection{System częściowo zdecentralizowany}

System ten występuje w sześciu krajach: w Belgii, Chorwacji, Danii, Finlandii, w Polsce i w Szwecji. Jego cechą charakterystyczną jest przekazanie części odpowiedzialności za sektor ochrony zdrowia ze szczebla centralnego na poziom lokalny lub regionalny. Przykładowo w Szwecji, Finlandii i Danii władze lokalne są odpowiedzialne za organizację świadczeń podstawowych i średnich. W wymienionych krajach (z wyjątkiem Belgii) fundusze na opiekę zdrowotną pochodzące z budżetów samorządowych (jako\% PKB) znacznie przekraczają zaangażowanie finansowe budżetu krajowego. W systemach częściowo zdecentralizowanych władze samorządowe są właścicielami placó- 
wek opieki zdrowotnej i odpowiadają za zarządzanie nimi. Posiadają również kompetencje ustalania (pośrednio lub bezpośrednio) ich planów finansowych oraz są zaangażowane finansowo i organizacyjnie w promocję zdrowia i działania profilaktyczne. Powyższe kraje charakteryzują się różnym poziomem decentralizacji, który ulega ciągłym modyfikacjom. W Belgii reforma z 2014 r. przekazała władzom regionalnym kosztem szczebla centralnego więcej zadań oraz szerszą odpowiedzialność. W Chorwacji przygotowywane są reformy dotyczące modyfikacji kompetencji i zasad fiskalnych pomiędzy samorządem terytorialnym a władzą centralną. W Finlandii reforma w zakresie ochrony zdrowia, usług socjalnych i administracji regionalnej ma wejść w życie w 2020 r. i zakłada ona przeniesienie odpowiedzialność opieki zdrowotnej z poziomu lokalnego na nowo utworzone władze regionalne. W Polsce reforma systemowa służby zdrowia z 2016 r. zatrzymała proces komercjalizacji i prywatyzacji szpitali publicznych, trwają również prace nad zmianą zasad finansowania służby zdrowia. Podobnie jak w systemach zdecentralizowanych, w systemach częściowo zdecentralizowanych mogą wystąpić różnice w dostępie i jakości usług opieki zdrowotnej (np. w Szwecji i Finlandii) w wyniku różnic w poziomach autonomii i możliwości finansowych władz lokalnych i regionalnych.

\subsection{System operatywnie zdecentralizowany}

System operatywnie zdecentralizowany obejmuje dziewięć krajów: Bułgarię, Czechy, Estonię, Litwę, Łotwę, Rumunię, Słowację, Słowenię i Węgry. W tych krajach wiodącą rolę w systemie ochrony zdrowia pełnią władze centralne, zaś rola samorządów terytorialnych ogranicza się do prowadzenia części placówek opieki zdrowotnej (funkcja operatywna). Finansowanie zadań związanych z ochroną zdrowia z budżetów lokalnych jest relatywnie niewielkie i niższe niż udział krajowy. Zakres systemu operatywnie zdecentralizowanego w poszczególnych krajach jest mocno zróżnicowany - szersze kompetencje posiada np. samorząd terytorialny Czech i Litwy, mniejsze Węgier. 
Robert Musiałkiewicz, Sylwia Sobczak - Rola jednostek samorzq̨du...

\subsection{System $w$ większości scentralizowany}

System w większości scentralizowany obejmuje trzy kraje: Francję, Holandię i Portugalię. W tych krajach odpowiedzialności za funkcjonowanie systemu ochrony zdrowia przypisana jest rządowi centralne$\mathrm{mu}$, niemniej władze lokalne i regionalne posiadają pewne zadania związane ze zdrowiem publicznym, partycypują również $\mathrm{w}$ wydatkach na służbę zdrowia, choć w dużo mniejszym zakresie niż władze centralne. We Francji i w Portugalii na poziomie lokalnym zadania związane $\mathrm{z}$ ochroną zdrowia realizują terenowe jednostki administracji centralnej.

\subsection{System scentralizowany}

System scentralizowany obejmuje pięć krajów: Cypr, Grecję, Irlandię, Luksemburg i Maltę. W tych krajach odpowiedzialność za ochronę zdrowia przypisana jest władzy centralnej, do której zadań należy jej finansowanie, zarządzanie placówkami opieki zdrowotnej, dbanie o należytą jakość świadczonych usług. Placówki opieki zdrowotnej są własnością państwa. W Irlandii i Grecji na poziomie lokalnym zadania związane z ochroną zdrowia realizują terenowe jednostki administracji centralnej.

\section{Podsumowanie}

Systemy ochrony zdrowia poszczególnych państw członkowskich UE w kontekście roli i znaczenia samorządu terytorialnego różnią się między sobą w istotnym stopniu. Różnice te dotyczą przede wszystkim uprawnień kompetencyjnych samorządu terytorialnego, zasad finansowania, zasad odpowiedzialności i praw własności obiektów opieki zdrowotnej. Przyczyn owych różnic należy się doszukiwać w historii poszczególnych krajów członkowskich, w ich tradycji, systemie wartości, obowiązujących rozwiązaniach ustrojowych czy stopniu zaufania do wolnego rynku. Analiza poszczególnych systemów ochrony zdrowia w skali wszystkich 28 państw członkowskich UE wskazuje 
na ważną rolę władz lokalnych i regionalnych w tym obszarze. Samorządy terytorialne 23 państw są zaangażowane w finansowanie systemu opieki zdrowotnej, niemniej jego poziom jest zróżnicowany w przypadku pięciu państw przekracza 50\% łącznych wydatków na ochronę zdrowia, z kolei w przypadku 7 państw jest mniejszy niż 5\%. W dziewięciu państwach członkowskich zaangażowanie samorządu terytorialnego $\mathrm{w}$ finansowanie ochrony zdrowia jest wyższe niż poziom finansowania z budżetu państwa. W zdecydowanej większości przypadków rola samorządu terytorialnego nie ma charakteru nadrzędnego nad polityką krajową. Tylko w pięciu państwach członkowskich władze lokalne i regionalne posiadają samodzielne kompetencje do stanowienia przepisów dotyczących polityki zdrowotnej, w pozostałych krajach jest to wyłącznie domena władzy centralnej. Owo zróżnicowanie modeli zarządzaniem systemami ochrony zdrowia i różnej roli samorządów terytorialnych pozwala na wyodrębnienie następujących modeli: zdecentralizowanego, częściowo zdecentralizowanego, operatywnie zdecentralizowanego, w większości scentralizowanego oraz scentralizowanego, do których na podstawie przede wszystkim zasad finansowania i uprawnień można przypisać określone kraje członkowskie wykazujące wspólne cechy. Zróżnicowana rola samorządu terytorialnego $\mathrm{w}$ prowadzeniu polityki ochrony zdrowia jest następstwem zróżnicowania państw Unii Europejskiej ze względu na stopień i charakter decentralizacji. W tych krajach, gdzie stopień decentralizacji jest znaczny (Francja, Niemcy), samorząd terytorialny posiada najszersze kompetencje $\mathrm{w}$ zakresie kształtowania polityki ochrony zdrowia, z kolei w krajach charakteryzujących się niskim stopniem decentralizacji zadania z zakresu ochrony zdrowia zostały przyporządkowane administracji centralnej.

\section{Bibliografia:}

Faliński S., Zróżnicowanie samorzq̨du terytorialnego w państwach Unii Europejskiej, KNUV 2014, nr 3. 
Robert Musiałkiewicz, Sylwia Sobczak - Rola jednostek samorzq̨du...

Izdebski H., Kulesza M., Administracja publiczna. Zagadnienia ogólne, Wyd. Liber, Warszawa 2004.

Izdebski H., Samorząd terytorialny. Podstawy ustroju i działalności, Wyd. Wolters Kluwer, Warszawa 2011.

Izdebski H., Polski samorzq̨ terytorialny w Europie. Aktualne problemy $i$ wyzwania, K. Czarnecki, A. Lutrzykowski, R. Musiałkiewicz (red.), Samorzq̨d terytorialny w Polsce i Europie. Aktualne problemy i wyzwania, Wyd. PWSZ we Włocławku, Włocławek 2017.

Jasiński G, Wybrane aspekty organizacji i metod finansowania systemów ochrony zdrowia w państwach europejskich, „Biuletyn Kas Chorych” 2001, nr 3-4.

Jończyk J., Zasady i modele ochrony zdrowia, Państwo i Prawo 2010, nr 8.

Joumard I., André C., Nicq C., Health Care Systems: Efficiency and Institutions, OECD Economics Department Working Papers, No. 769, OECD Publishing; http://www.oecd-ilibrary.org/economics/health-care-systems_5 kmfp51 f5f9ten.

Kautsch M, Whitfield M., Klich J. (red.), Zarządzanie w opiece zdrowotnej, Wyd. UJ, Kraków 2001.

Nojszewska E, System ochrony zdrowia w Polsce, Wyd. Wolters Kluwer Polska, Warszawa 2011.

Kluczyńska M., Grzywacz J., System finansowania publicznej opieki zdrowotnej w Polsce $w$ świetle doświadczeń niemieckich; „Zeszyty Naukowe PWSZ w Płocku Nauki Ekonomiczne" 2015, t. XXII.

Piotrowska - Marczak K., Marczak J., Uryszek T., Obszary konfliktów w systemie finansowym, „Dny práva - 2009 - Days of Law: the Conference Proceedings, 1. Edition". Masaryk University, 2009.

Suchecka J. (red.), Finansowanie ochrony zdrowia: Wybrane zagadnienia, Wyd. Wolters Kluwer Polska, Warszawa 2001.

Rutkowska-Podołowska M., Popławski Ł., Zaleska-Tsitini M., Health care policy in Poland and in selected European Union countries: Attempts at reducing fast increasing medical care costs, The Małopolska School Of Economics in Tarnów, Papers Collection 2011, nr 19.

Soldi R, Odone C., he management of health systems in the EU Member States The role of local and regional authorities; Committee of the Regions EU.

Wielicka K., Zarys funkcjonowania systemów opieki zdrowotnej w wybranych krajach Unii Europejskiej, „Zeszyty Naukowe. Organizacja i Zarządzanie Politechnika Śląska” 2014, nr 70. 
Hope \& Dexia, Hospitals in the 27 Member States of the European Union, Dexia Editions 2009; http://www.hope.be/wp-content/uploads/2015/11/79_ 2009_OTHER_Hospitals-in-27-Member-Statesof-the-European-Union-eng. pdf. 
